\title{
Understanding maternal dietary behaviour and perceived attributes of foods in the context of food insecurity in rural Bangladesh: a qualitative study
}

\author{
Wajiha Khatun', Sabrina Rasheed ${ }^{2}$, Michael J Dibley', Ashraful Alam \\ 1 The University of Sydney School of Public Health, The University of Sydney, NSW, Australia, ${ }^{2}$ International Centre for Diarrhoeal Disease Research, \\ Bangladesh, Dhaka, Bangladesh \\ Keywords: bangladesh, qualitative methods, pregnant and lactating women, food attributes, perceptions \\ https://doi.org/10.29392/001c.12326
}

\section{Journal of Global Health Reports}

Vol. 4, 2020

\section{Background}

Evidence shows inadequate dietary diversity among women in resource poor settings in developing countries. We explored women's perceived attributes related to food choices to understand their eating habits during pregnancy and lactation, in rural Bangladesh.

\begin{abstract}
Methods
We conducted a qualitative study in two villages in Jamalpur District in northern Bangladesh. These villages experience high levels of poverty according to the 2010 Bangladesh Poverty Map. We undertook in-depth interviews $(n=36)$ with pregnant and lactating women and conducted focus group discussions $(n=2)$ with their husbands. We used the ProPAN (Process for the Promotion of Child Feeding - a tool to improve infant and young child feeding) methodology to develop a key food list to conduct the food attribute exercise. Data was audio-recorded, transcribed in Bangla, and translated into English. The transcripts were manually coded and analyzed using the inductive thematic approach.
\end{abstract}

\section{Results}

We found that: (i) animal-source foods and fruits were the least consumed in the women's diet resulting in low dietary diversity; (ii) Consumption of diversified foods was influenced by access to food at home, while accessibility depended on affordability and availability in the local market or homestead gardens; and (iii) even though food was available and accessible at the household level, individual food choice and consumption were subject to personal preference, cultural norms and lack of knowledge about nutritious foods and subsequent health benefits during pregnancy and lactation.

\section{Conclusions}

The findings will assist in planning appropriate interventions to improve dietary diversity of pregnant and lactating women. Insights from this study will be useful for designing appropriate nutrition behaviour change communication in Bangladesh and other low-resource settings.

Dietary diversity has been identified as a proxy indicator for dietary quality and micronutrient adequacy in women from resource-poor settings in developing countries. ${ }^{1-5}$ These women are at high risk of inadequate intake of multiple micronutrients as their diet is dominated by starchy staples with limited micronutrient dense foods such as animal source foods. ${ }^{6,7}$ Research shows that poor families in rural areas spend a larger proportion of their income on purchasing starchy staples, and spend less money buying diversified, nutrient-rich foods as a result of food price rises. ${ }^{8-11}$ Moreover, during times of food insecurity, intra-household food allocation is less favourable to women, who compromise on quantity and diversity of food to ensure sufficient meals for their husbands and children. ${ }^{12-14}$ Evidence from South Asia, including Bangladesh, shows that food allocation at household level is greatly influenced by family income, affordability, purchasing power, dietary behaviour, socio-economic status, personal preferences and inter-personal relationships. ${ }^{15}$ Research also shows that these factors, along with women's perceived attributes of foods such as health benefits, taste, smell and acceptability, influence their choice of foods for child feeding. ${ }^{16,17}$ In addition, cultural beliefs and food taboos can restrict women's dietary quality and quantity during pregnancy and lactation. ${ }^{14,18,19}$ A study in rural Bangladesh revealed that pregnant women had a low intake of micronutrient rich foods like dark green 
leafy vegetables and animal source foods despite their awareness of the importance of these foods. ${ }^{20}$

Although earlier studies in South Asia have explored the social norms, beliefs and cultural factors related to the dietary behaviour of pregnant and lactating women, there are still gaps in understanding community perceptions about the attributes of foods consumed during pregnancy and lactation, especially in resource poor settings.

Therefore, our aim is to explore pregnant and lactating women's perceived food attributes to characterize personal, behavioural and environmental factors related to dietary behaviour.

\section{MATERIALS AND METHODS}

\section{STUDY SITE AND POPULATION}

We conducted a qualitative study in two villages of Melandah upazila (sub-district) of Jamalpur districts in northern Bangladesh. Melandaha upazila was selected as more than $60 \%$ of the population are considered poor, with nearly half of the population (47\%) extremely poor according to the 2010 Bangladesh Poverty Map. ${ }^{21}$ In this impoverished rural region less than one in ten household heads had completed primary education. The feasibility of recruiting an adequate number of pregnant and lactating women was carefully considered. We visited the local BRAC office, the largest NGO in Bangladesh, to seek assistance in selecting and accessing the communities. We visited the community clinics, as advised by BRAC staff, to obtain a list of the pregnant and lactating women in selected villages. We collected data in two phases -from January to February 2015, and from May to June 2015.

\section{PARTICIPANTS}

A total of 36 pregnant and lactating women were purposively selected for in-depth interviews (IDI) using sampling techniques adopted from ProPAN (Process for the Promotion of Child Feeding - a tool to improve infant and young child feeding) methodology. ${ }^{22}$ The field research team consulted the community health workers to obtain a list of eligible pregnant and lactating women currently receiving antenatal care and postnatal care services. We selected women who were pregnant at the time of data collection, had delivered a live baby in the past two years, or had a child 0-23 months of age. A total of 36 IDIs were conducted in two phases (16 pregnant, 18 lactating women, and 2 pregnant and lactating women).

\section{ETHICAL APPROVAL}

We obtained ethical approval from the Human Research Ethics Committee, University of Sydney (Ref.: 2014/874). In Bangladesh, the study was approved by the Ethical Review Committee of the International Centre for Diarrhoeal Disease Research, Bangladesh (Ref.: PR-14101/2014). Informed written and oral consents were obtained from respondents at each stage of the study.

\section{DATA COLLECTION METHODS}

We recruited two experienced qualitative researchers, who were then trained in data collection tools by an investigator (WK) (a nutritionist and skilled qualitative investigator). Data was collected using in-depth interviews, focus group discussion, market surveys, and food attribute exercises using methods and tools adapted from ProPAN - an approach to capture infant feeding practices through the development of a key food list and food attribute exercises. ${ }^{22}$

\section{KEY FOOD LIST DEVELOPMENT PROCESS}

We developed a key food list based on the results of indepth interviews on dietary assessment, and from focus group discussions and market surveys (Table 1). The key food list, which included 25-30 foods, was developed based on five criteria: 1) foods frequently consumed by the women; 2) sources of important nutrients, especially protein, iron, and calcium; 3) availability and affordability in the local markets 4 ) homestead produce or readily available free foraged foods and 5) seasonal availability.

Out of 36 in-depth interviews, we conducted 20 interviews to explore the usual food intake and dietary pattern of the pregnant and lactating women. For the structured faceto-face interviews, we used an open-ended format to generate data about the foods consumed by the women in the previous day (24-h dietary recall) and in the last seven days (7-day recall). The respondents were also asked about their dietary history and the daily variations in diets until a full picture of food variety was obtained, and enabled us to understand their daily dietary patterns.

Based on the results on the 24-hour and 7-day recall and discussion on dietary history, a list of foods was compiled from the various food groups usually consumed by the women (eg, cereals, lentils/legumes, roots and tubers, vegetables, fruits, fish, meat, egg, milk and milk products, oils). Foods mentioned more often in the 24-hour recalls and dietary history were considered as the most frequently consumed foods. Similarly, foods that appeared less often in the 24-hour dietary recalls but appeared in the 7-day dietary recalls and sometimes mentioned in the dietary history were considered as the less frequently consumed foods. Foods that were consumed a few times in a month/six months/year and hardly mentioned in the dietary history were considered as the rarely consumed foods (Table 1).

Two focus group discussions (FGD) were conducted with the husbands of the women. The FGDs engendered information about the availability of foods in the local market, food costs, seasonal availability, homestead production and access to free foraged foods. This information helped identify a list of locally available and affordable, seasonal foods.

The foods listed were grouped according to their source of origin and nutritive values, for example, animal source foods (egg, chicken, beef, small fish, large fish, and dried fish and milk/dairy products), green leafy vegetables, other vegetables, fruits, nuts/seeds, and beans. Animal source foods were also selected as rich sources of protein and minerals such as iron, zinc, and calcium, while vegetable and fruits were regarded as the source of vitamins such as Vitamins A, C, B, and folate. We reviewed the "Food Composi- 
tion Table for Bangladesh"23 to select foods rich in protein, iron and calcium and other vitamins (Vitamin C, and folate) (Table 1). Hence, based on the information, we developed an initial list of key foods to use for the market survey.

For the market survey, we selected and visited two local markets where the household members of respondents usually purchased foods. In these markets, local farmers gathered every morning (and once a week in a larger scale) to sell their own produce including vegetables, fruits, fishes, eggs and chickens in small quantities, although there were some small permanent grocery shops. We interviewed the mobile sellers and grocers to collect information on availabile foods, the retail price per unit, and seasonal availability. Although the market survey was conducted in winter, the sellers and the grocers were asked about the foods available in the market in the other seasons as well. The survey was important to capture the seasonal variations of foods, especially for fruits and vegetables, as the seasonal foods were available at low-cost in the local market. The list of the key foods is presented in Table 1. The key food list was developed to use for the food attribute exercises in the next step of the study.

\section{FOOD ATTRIBUTE EXERCISES}

We asked women about their perceptions, attitudes and practices on the consumption of a variety of foods from the list of key foods presented in Table 1. The interviewers named these foods and asked for information on whether they were consumed or not, the reasons for consuming/not consuming, the food preparation process and the necessary conditions for consumption if advised to consume the food.

\section{DATA ANALYSIS}

Interviews were audio-recorded, transcribed in Bangla, then translated into English. The quality of translations was discussed within the team. An inductive coding method was used, themes were generated from the data pertinent to the research questions. ${ }^{24}$ Initially, two transcripts were coded and discussed to finalize the codes. According to the final thematic codes, all transcripts were manually coded and analysed using inductive thematic approach. ${ }^{25}$ Through iterative discussions among the research team, the data were analyzed to find variations, similarities, and emerging trends in themes generated through the coding process (Figure 1).

\section{RESULTS}

\section{CHARACTERISTICS OF THE STUDY PARTICIPANTS}

The pregnant and lactating women that participated in this study were aged between 15-35 years and married at the time of the study. All of them completed primary education, while most attained secondary education. The husbands of the respondents were typically the head of the household and had attained either the primary or secondary education and were day labourers and shop keepers by occupation. Most of the women reported that their husbands were the main income earners in the family and they could hardly manage livelihoods with their income, while some of them can manage their basic necessity only. Many respondents stated that they had often insufficient foods available at home to feed the family.

\section{ATTRIBUTES OF DIVERSIFIED FOOD GROUPS}

We found that women's food choices were related to their perceptions on positive and negative attributes of food. Moreover, women reported that their selection of foods for consumption is influenced by health beliefs, social norms, convenience of preparation and acceptability.

\section{ATTRIBUTES OF ANIMAL SOURCE FOODS}

Respondents perceived that animal foods, such as egg, meat, fish and milk, were sources of important nutrients, and were beneficial for both woman and child's health and nutrition. Generally, eggs and milk were preferred during pregnancy and lactation as both were easy to prepare and good for health. For example, a mother said,

\section{"I eat an egg every day. Both the local hen's egg and farmed egg. Previously I don't eat egg but now I eat every day. As because it is advised by a doctor."}

However, a few women associated animal source foods with miscarriage and allergic reactions. The women reported that local and traditional healers advised them to restrict consumption of animal source foods during pregancy and lactation. In addition, some women reported experiencing indigestion and a bloated stomach after consuming milk. Other women mentioned personal preference for foods in relation to taste, smell and texture as important considerations when consuming animal source foods. For example, meat and fish were often considered too smelly, and eggs were regarded as baby food. (Table 2).

\section{ATTRIBUTES OF FRUITS AND VEGETABLES}

We found that vegetables, including green leafy vegetables, were acceptable during pregnancy and lactation (Table 2). Most women perceived that vegetables were nutritious a good source of vitamins and beneficial for maternal and child health. However, many of them believed that some green leafy vegetables had adverse effects such as causing cold, itching, gastric problems and allergy. Some mothers also complained about the taste. However, a few mentioned that they used cooking techniques to make the food more palatable to consume. For example, arum leaves which are good source of iron were thought to cause throat itching and some mothers mentioned cooking processes such as adding lemon juice, boiling or mashing the leaves, or stirfrying to evaporate the water as ways to prevent itching. A few mothers added dry fish to vegetable dishes to enhance their flavour and render them more palatable. For example, a mother said,

\footnotetext{
"Vegetables are not always palatable. So we add a small amount or of dry fishes, mostly a few pieces of the small dry fishes that either made at home or buy from the local markets while cooking vegetable dish to make it delicious."
} 


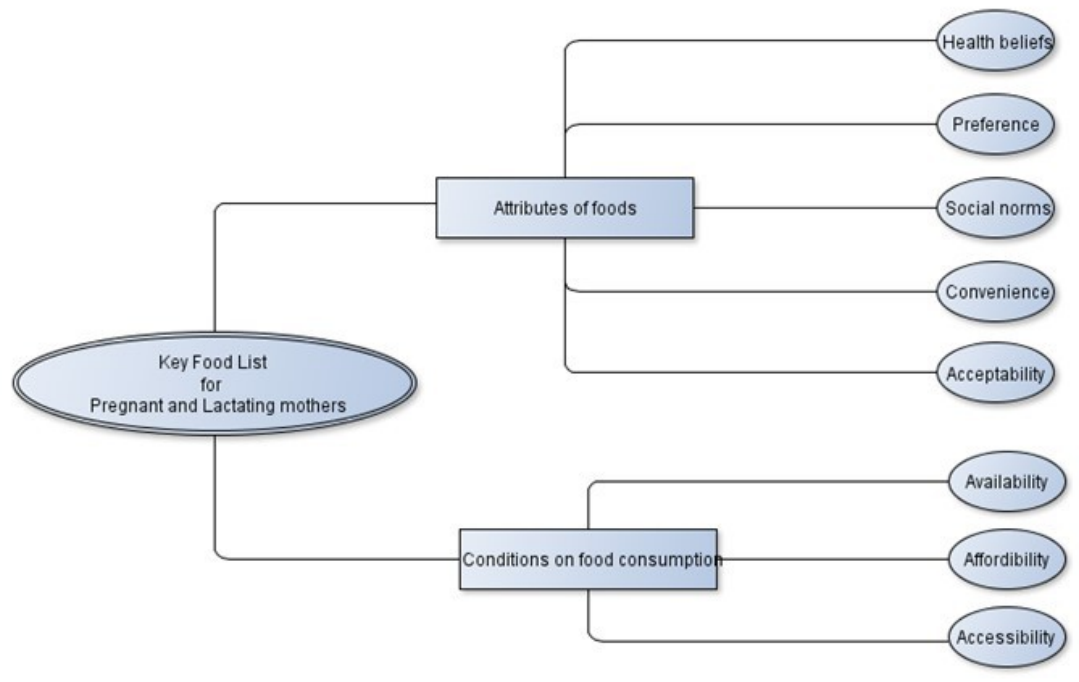

Figure 1. Code tree.

\section{ATTRIBUTES OF LEGUMES, SEEDS AND NUTS}

The women consumed legumes and found them acceptible, yet they did not like seeds (Table 2). There was a belief that lentil intake produces more breastmilk and, as a result, lactating women strive to consume lentil soup or mashed legumes. However, some women preferred to consume fried seeds and nuts as snacks or appetizers in pregnancy.

\section{CONDITIONS RELATED TO CONSUMING A DIVERSIFIED DIET}

Women reported the conditions and factors that influenced their consumption of diversified food groups (Table1). They would consume important foods when they had access to the different food groups at home. Access to foods depended on availability of foods at the local markets, seasonal variations and homestead food production. Availability of food in the market depended on seasonality and farming practices, for example, large catfish and carp (from local fisheries) were usually lower in cost and therefore more affordable for the family compared with beef and small fish. Beyond the market, homestead poultry production and gardening enabled them to obtain eggs, chicken and seasonal fruits and vegetables at home. Moreover, some of the women reported that they had easy access to green leafy vegetables that grew in and around the homestead or source from foraging on nearby land. They collected the leafy vegetables to consume when no other food groups were avail- able except rice, to cope with food scarcity. A mother said,

"Some of the leafy vegetables are naturally grown in our back and front yards and we grow them in our home garden. ...There have been no vegetables at home. I have collected some arum leaves to eat. I also collect other leafy vegetables to cook when there is a lack of foods at home."

However, the high price of food was found to be a barrier to access, particularly for nutritious foods like such as beef, chicken, lentils or fruits. Most of the families in this study could not afford these foods, and as a result, cheaper foods were often purchased and consumed. As one mother said,

"The price of the anchor (a type of legume) is lower than other legumes. So that we buy this one. We do not eat it daily. When there are no other foods to eat, we eat legumes."

Another important barrier to food consumption for some respondents was limited access to the market. Often foods brought home were chosen by husbands or male family members and were not available if the men were unable to shop for the family. A woman said,

“We can't eat beef as we don't have male members at home to go for shopping. Only me and my mother-inlaw are at home. My husband and his brother are living in the city for their job. When they come back, they do shopping." 
In food insecure households, the women spoke about sacrificing foods for children and other family members and this adversely affected their dietary diversity, as a woman said,

"My child has been eaten lichi and banana since last month but not me. If I eat, my child cannot eat the next time. I eat when enough amount of fruit is bought for the family. But we cannot even manage to give to the child always. As a little amount of fruit is usually available at home, I cannot eat it."

\section{DISCUSSION}

Our study is one of the very few studies in Bangladesh that addresses women's food choice and dietary behaviours in the context of poor, low-income households in rural communities. We found that two aspects of food security; availability and accessibility, were an important influence on maternal dietary diversity. Existing social norms and personal food choices also played a significant role.

A key finding of our study was that consumption of diversified foods was greatly influenced by access to food at home, while accessibility depended on affordability and availability in the local market. We found that consumption of seasonal fruits and vegetables was often preferred due to their availability at low cost in the local market. This also implies that seasonal variations could affect household food security and dietary diversity. ${ }^{26}$ However, despite availability in the local market, many households could not afford nutrient-rich animal source foods, lentils, and fruits due to high prices. Prior research also suggests that food price is a major issue for food access because low-income families select only the foods they can afford to buy. ${ }^{27,28}$ Moreover, similar to other studies, ${ }^{15,29}$ women having no access to markets and the husband's food preferences, were potential barriers to women accessing foods of their choice. However, limited access to food at home might affect consumption of nutrient-rich foods, especially animal source foods, and fruits. ${ }^{30}$ Therefore, in order to improve the consumption of a variety of food groups it is important to ensure that women have access to their choice of foods at home, especially during pregnancy and lactation.

Besides availability and accessibility, women's eating behaviour was highly influenced by their food preference and the acceptability of particular foods, especially during pregnancy. Previous research reports pregnant women's aversion to specific foods reduced consumption of those foods. ${ }^{31}$ Similar to other studies, we found that food preferences were influenced by sensory characteristics of foods such as taste, flavour and texture. ${ }^{32,33}$ However, despite personal preferences, women may still avoid eating nutrient-rich foods due to social norms and health beliefs. These findings were consistent with other studies that report that social norms and health beliefs have an important role in food restrictions in many countries, including Bangladesh. ${ }^{14,33}$

A notable finding of our study was the important contribution of homestead production of fruits, vegetables and poultry which made these foods available and accessible to poor women, with similar findings reported in other stud- ies. ${ }^{34,35}$ Furthermore, we found that plenty of green leafy vegetables grew naturally as foraged foods around the homestead and in the abandoned areas in the neighbourhood. According to the Food Composition Table for Bangladesh, these vegetables such as water spinach (kolmi shak), and arum leaves or colocasia leaves or taro leaves (kochu shak) are rich in iron, calcium, folic acid, and vitamins B6 and C. ${ }^{23}$ The women had easy access to these leafy vegetables, which were free of cost, especially during food insecure times. Therefore, this could be a cost-effective way to encourage consumption of leafy vegetables, one of the ten food groups recommended for women's dietary diversity.

The strength of our study is a qualitative approach to produce a rich description of the context in which women's food choices were made. In this study, triangulation of different data collection methods such as in-depth interviews, focus-group discussions and food attribute exercises increased the quality of the data. The study also had some limitations. We did not collect information from family members who might have influenced women's diets. We also did not interview community health workers who provide nutrition information during an antenatal check-up and home visits. Further research is needed to investigate the views of more comprehensive group of respondents.

\section{CONCLUSIONS}

Our study showed that household food security is necessary but not enough to ensure dietary diversity of pregnant and lactating women. In food-insecure households, homestead food production and free or low-cost access to essential foods is an important consideration for programming. For maximum benefit, context-specific behaviour change communication that considers social norms and personal preferences as well as appropriate local food production for potentially nutritious foods should be provided to women. The findings of the study will benefit programme and policy makers to design behaviour change communication that aims to improve the dietary diversity among pregnant and lactating women in Bangladesh and other low resource settings.

Acknowledgements: This study was supported by the University of Sydney. We are grateful to the Australia Awards-Endeavour Scholarships and Fellowships for funding WK's PhD at the University of Sydney and the approval of fieldwork in Bangladesh. The field data collection was performed with the support of the International Centre for Diarrhoeal Disease Research, Bangladesh (icddr,b). We thank the research team of icddr,b for their valuable efforts in data collection. Above all, we are grateful to the respondents who provide their time and views. We acknowledge Elizabeth Kirkwood for her editorial support.

Funding: This work was supported by the Bill \& Melinda Gates Foundation, Seattle, WA, USA [Grant number 1107952]. The funding source had no role in the study de- 
sign, data analysis, data interpretation, or writing of the manuscript.

Authorship contributions: WK designed the study and developed the tools with AA and SR. WK carried out the data collection, analysis, interpretation of results along with the support of AA and SR. AA supervised the study. WK developed the first draft of the manuscript with support from AA, SR, and MJD critically reviewed the manuscript. WA and AA responded to reviewers' comments and revised the manuscript. All the authors approved the manuscript as submitted.

Conflicts of interest: The authors completed the Unified Competing Interest form at http://www.icmje.org/coi disclosure.pdf (available upon request from the corresponding author), and declare no conflicts of interest.

\section{Correspondence to:}

Ashraful Alam, PhD, MSS.

Senior Research Fellow in Medical Anthropology

The University of Sydney School of Public Health

Edward Ford Building (A27)

The University of Sydney

New South Wales, 2006

Australia

neeloy.alam@sydney.edu.au 
Table 1. Summary of the key food list and its selection criteria

\begin{tabular}{|c|c|c|c|c|c|}
\hline \multirow[t]{3}{*}{ Key foods } & \multicolumn{5}{|c|}{ Selection criteria } \\
\hline & \multirow{2}{*}{$\begin{array}{l}\text { Consumed } \\
\text { (0=rarely; } \\
1=\text { Less; } \\
2=\text { mostly) }\end{array}$} & \multirow[t]{2}{*}{$\begin{array}{l}\text { Nutrient of } \\
\text { interest }\end{array}$} & \multicolumn{3}{|c|}{$\begin{array}{l}\text { Availability, } \\
Y=\text { Yes, } N=\text { No }\end{array}$} \\
\hline & & & $\begin{array}{l}\text { Local } \\
\text { Market }\end{array}$ & $\begin{array}{l}\text { Home } \\
\text { produce/ } \\
\text { forage }\end{array}$ & Seasonal \\
\hline \multicolumn{6}{|l|}{ Protein-rich animal foods: } \\
\hline Egg & 1 & Fe, Zn, Vit A\&D & $\mathrm{Y}$ & $\mathrm{Y}$ & $\mathrm{N}$ \\
\hline Chicken & 1 & $\mathrm{Fe}, \mathrm{Zn}$ & Y & Y & $\mathrm{N}$ \\
\hline Beef & 0 & $\mathrm{Fe}, \mathrm{Zn}$ & $\mathrm{N}$ & $\mathrm{N}$ & $\mathrm{N}$ \\
\hline Milk/milk products & 1 & $\mathrm{Ca}$ & $\mathrm{N}$ & $\mathrm{Y}$ & $\mathrm{N}$ \\
\hline Fish (big)(rui, mrigel) & 1 & $\mathrm{Fe}, \mathrm{Zn}$ & $\mathrm{Y}$ & $\mathrm{N}$ & $\mathrm{N}$ \\
\hline Fish (small)(mola, dhela) & 1 & $\mathrm{Ca}$ & $\mathrm{Y}$ & $\mathrm{N}$ & $\mathrm{Y}$ \\
\hline Fish (dried)(shutki) & 2 & $\mathrm{Ca}$ & $\mathrm{Y}$ & $\mathrm{Y}$ & $\mathrm{N}$ \\
\hline \multicolumn{6}{|l|}{ Carbohydrate-rich foods: } \\
\hline Rice & 2 & Energy & Y & $\mathrm{N}$ & $\mathrm{N}$ \\
\hline Potato & 2 & Energy & $\mathrm{Y}$ & $\mathrm{N}$ & $\mathrm{N}$ \\
\hline \multicolumn{6}{|l|}{ Leafy vegetables: } \\
\hline Watercress, Water spinach & 1 & Fe, Vit C & $\mathrm{Y}$ & $\mathrm{Y}$ & $\mathrm{N}$ \\
\hline $\begin{array}{l}\text { Colocasia leaves, Taro leaves, } \\
\text { Amaranth leaves }\end{array}$ & 1 & $\begin{array}{l}\text { Ca, Fe, folate, } \\
\text { Vitamin B6, C }\end{array}$ & Y & Y & $\mathrm{N}$ \\
\hline $\begin{array}{l}\text { Indian spinach, Bottle gourd } \\
\text { leaves, Radish leaves }\end{array}$ & 1 & $\mathrm{Ca}, \mathrm{Fe}, \mathrm{Vit} \mathrm{C}$ & Y & $\mathrm{Y}$ & Y \\
\hline $\begin{array}{l}\text { Jute leaves, Pumpkin leaves, } \\
\text { Grass pea leaves }\end{array}$ & 1 & Ca, Vit C & Y & $\mathrm{Y}$ & $\mathrm{N}$ \\
\hline \multicolumn{6}{|l|}{ Other vegetables: } \\
\hline Eggplant, Tomato & 2 & $\begin{array}{c}\text { Vit B\&K, folate, } K, \\
\text { Mn, fiber }\end{array}$ & Y & Y & $\mathrm{N}$ \\
\hline Bean, Cauliflower, Bottle gourd & 2 & $\begin{array}{l}\text { Vit B\&K, folate, } K, \\
\text { Mn, fiber }\end{array}$ & Y & $\mathrm{Y}$ & $\mathrm{Y}$ \\
\hline Ash gourd & & $\begin{array}{l}\text { Vit B\&K, folate, } K, \\
\text { Mn, fiber }\end{array}$ & Y & $\mathrm{Y}$ & Y \\
\hline \multicolumn{6}{|l|}{ Fruits: } \\
\hline Banana, tamarind & 1 & $\mathrm{Fe}$ & $\mathrm{Y}$ & $\mathrm{Y}$ & $\mathrm{N}$ \\
\hline Papaya (Ripe/Green) & 1 & Vit A\&C & $\mathrm{Y}$ & $\mathrm{Y}$ & $\mathrm{N}$ \\
\hline Mango, Black plum, Jackfruit & 1 & Vit A & $\mathrm{Y}$ & $\mathrm{Y}$ & $\mathrm{Y}$ \\
\hline Jujube, Indian olive & 1 & Vit C & $\mathrm{Y}$ & $\mathrm{Y}$ & $\mathrm{Y}$ \\
\hline Lemon & 1 & Vit C & $\mathrm{Y}$ & $\mathrm{Y}$ & $\mathrm{N}$ \\
\hline Pumpkin /sweet gourd & 2 & Vit A & Y & $\mathrm{Y}$ & $\mathrm{N}$ \\
\hline \multicolumn{6}{|l|}{ Legume\& nuts: } \\
\hline Lentil & 1 & Protein, Zn, K, Mn & $\mathrm{N}$ & $\mathrm{N}$ & $\mathrm{N}$ \\
\hline Anchor & 1 & Protein & $\mathrm{Y}$ & $\mathrm{N}$ & $\mathrm{N}$ \\
\hline Groundnut & 1 & Protein & $\mathrm{N}$ & $\mathrm{N}$ & $\mathrm{N}$ \\
\hline
\end{tabular}


Table 2. Women’s perceptions on attributes of diversified food groups

\begin{tabular}{|c|c|c|c|c|}
\hline Food groups & Positive attributes & Negative attributes & How to prepare & $\begin{array}{l}\text { Under what condition women consume different food } \\
\text { groups }\end{array}$ \\
\hline \multirow[t]{5}{*}{ Egg } & Nutritious; & Having bad smell form egg & Boiled & Family's affordability \\
\hline & & Dislike the taste & & \\
\hline & Good for health; & Mothers sacrifices food for child & & Access at home \\
\hline & Good for pregnancy outcome; & Dietary restrictions for pregnancy & Omelette & Homestead poultry produce \\
\hline & Easier and quicker to prepare. & $\begin{array}{l}\text { Food taboos - hot food, causes cold and } \\
\text { allergy }\end{array}$ & Egg curry & Awareness through nutrition $\mathrm{BCC}$ \\
\hline \multirow[t]{7}{*}{ Fish/meat } & Nutritious. & Meat is expensive than fish & Fish Curry with vegetables/seeds & Seasonal availability \\
\hline & & Food taboos- birth of a weak baby & & Availability in local market \\
\hline & Helps in brain development & Food restrictions by local healer & & Low price \\
\hline & Beneficial for eyesight (ie,small fish) & Dislike the smell of the fish & Mashed fishes & Family's affordability \\
\hline & Makes body strong & Loss of appetite in pregnancy & Fries fishes & Vendors carry door-to-door; \\
\hline & Appetizer (ie, dry fishes) & Husband's food choice get priority & Meat Thick curry (bhuna) & Access at home \\
\hline & Likes the taste of meat & No market access for women. & Kababs & Homestead poultry produce. \\
\hline \multirow[t]{6}{*}{ Milk/milk products } & Nutritious & Causes indigestion & Drink without adding water & Family's affordability \\
\hline & & & & Access at home \\
\hline & Beneficial for child health & Stomach bloating & & Homestead livestock produce \\
\hline & Good for pregnancy outcome & & Eat with rice & \\
\hline & Helps to sleep well & & Card & \\
\hline & Not adulterated. & Dislikes the smell and taste & Yogurt. & Advised by doctor \\
\hline \multirow{7}{*}{$\begin{array}{l}\text { Green leafy } \\
\text { vegetables }\end{array}$} & Nutritious & Causes vomiting & Curry with dry fish & Home garden produce \\
\hline & & Causes throat itching (ie, arum leaves) & & \\
\hline & Source of vitamin & Causes gastric/acidity problems & & Available in season \\
\hline & Source of iron (ie, arum leaves) & Causes cold and allergy & Boiled and mashed & Available at local market \\
\hline & Good for eye, health and pregnancy outcome & Do not like the smell and taste & Stir fried & Access at home \\
\hline & Like to eat. & No market access for women & Adding lemon juice while eating & Access to natural sources \\
\hline & & Discard the juice while cooking & & Awareness through nutrition BCC during ANC. \\
\hline \multirow[t]{6}{*}{ Other vegetables } & Nutritious & Causes vomiting & Stir fried. & Family's affordability \\
\hline & & & & Seasonal availability \\
\hline & Source of vitamin & Do not like the smell and taste & Curry with fish & Available at local market \\
\hline & Good for baby & Husband's food choice get priority & Cooked mixed vegetables & Homestead garden produce \\
\hline & & & Boiled and mashed & Access at home \\
\hline & & & & If women's food choice get priority \\
\hline \multirow[t]{5}{*}{ Fruits } & Nutritious & Expensive (imported fruits) & Eat fresh & Family's affordability \\
\hline & & & & Homestead garden produce \\
\hline & Source of vitamin & Do not like & Consume with milk and rice & Seasonal availability \\
\hline & Good for pregnancy & Dislike sourness & & Available at local market at low cost \\
\hline & Purifies blood & Preferred as child food & & Access at home \\
\hline
\end{tabular}




\begin{tabular}{|c|c|c|c|c|}
\hline Food groups & Positive attributes & Negative attributes & How to prepare & $\begin{array}{l}\text { Under what condition women consume different food } \\
\text { groups }\end{array}$ \\
\hline & \multirow[t]{2}{*}{ Good for health. } & \multirow[t]{2}{*}{ Not suitable for hot weather (ie, Jackfruit). } & & Gifts from neighbours/relatives \\
\hline & & & & Mass media awareness (ie,TV) \\
\hline \multirow[t]{4}{*}{ Legumes } & \multirow[t]{2}{*}{ Increases breastmilk production } & Dietary restrictions in pregnancy & $\begin{array}{l}\text { Mashed after boiling with onions and } \\
\text { chilli }\end{array}$ & Family can afford \\
\hline & & Expensive & Soup & Access at home \\
\hline & \multirow[t]{2}{*}{$\begin{array}{l}\text { Reduce vomiting (pregnancy); Fried legumes are good; appetizer } \\
\text { (chickpeas) }\end{array}$} & \multirow[t]{2}{*}{ Considered as cold foods } & Cooked with rice (khichuri) & \\
\hline & & & fried & If other foods are not available at home \\
\hline \multirow{4}{*}{ Nuts/seeds } & \multirow{4}{*}{ Good appetizer (Til, Tishi); Reduces vomiting. } & Causes common cold & \multirow{2}{*}{ Fried (nuts and beans) } & Available in local market \\
\hline & & Do not like the smell and taste & & Available in season \\
\hline & & Dietary restrictions in pregnancy & Dry roasted & Family can afford \\
\hline & & Prefer to feed child first. & Mashed (Til, Tishi, Kalijira) & Low price \\
\hline
\end{tabular}


This is an open-access article distributed under the terms of the Creative Commons Attribution 4.0 International License (CCBY-4.0). View this license's legal deed at http://creativecommons.org/licenses/by/4.0 and legal code at http://creativecommons.org/licenses/by/4.0/legalcode for more information. 


\section{REFERENCES}

1. Arimond M, Wiesmann D, Becquey E, Carriquiry A, Daniels MC, Deitchler M, et al. Simple food group diversity indicators predict micronutrient adequacy of women's diets in 5 diverse, resource-poor settings. $J$ Nutr. 2010;140(2059):2059S-69S. doi:10.3945/in.11 $\underline{0.123414}$

2. Kennedy G, Fanou N, Seghieri C, Brouwer ID. Dietary Diversity as a Measure of the Micronutrient Adequacy of Women's Diets: Results from Bamako, Mali Site. Washington, D.C.: Food and Nutrition Technical Assistance II Project, FHI 360; 2009.

3. Arimond M, Torheim LE, Wiesmann D, Joseph M, Carriquiry A. Dietary Diversity as a Measure of the Micronutrient Adequacy of Women's Diets: Results from Rural Bangladesh Site. Washington, D.C: Food and Nutrition Technical Assistance II Project, FHI 360; 2009.

4. Wiesmann D, Arimond M, Loechl C. Dietary Diversity as a Measure of the Micronutrient Adequacy of Women's Diets: Results from Rural Mozambique Site. Washington, D.C: Food and Nutrition Technical Assistance II Project, FHI 360; 2009.

5. Daniels MC. Dietary Diversity as a Measure of the Micronutrient Adequacy of Women's Diets: Results from Metropolitan Cebu, Philippines Site. Washington, D.C: Food and Nutrition Technical Assistance II Project, FHI 360; 2009.

6. Arsenault JE, Yakes EA, Islam MM, Hossain MB, Ahmed T, Hotz C, et al. Very low adequacy of micronutrient intakes by young children and women in rural Bangladesh is primarily explained by low food intake and limited diversity. J Nutr.

2013;143:197-203. doi:10.3945/jn.112.169524

7. Torheim LE, Ferguson EL, Penrose K, Arimond M. Women in resource-poor settings are at risk of inadequate intakes of multiple micronutrients. J Nutr. 2010;140:2051s-2058s. doi:10.3945/jn.110.123463

8. Bouis HE, Eozenou P, Rahman A. Food prices, household income, and resource allocation: Socioeconomic perspectives on their effects on dietary quality and nutritional status. Food Nutr Bull. 2011;32:S14-23. doi:10.1177/15648265110321S103

9. Torlesse H, Kiess L, Bloem MW. Association of household rice expenditure with child nutritional status indicates a role for macroeconomic food policy in combating malnutrition. J Nutr. 2003;133:1320-1325. doi:10.1093/jn/133.5.1320
10. Martin-Prevel Y, Becquey E, Tapsoba S, Castan F, Coulibaly D, Fortin S, et al. The 2008 food price crisis negatively affected household food security and dietary diversity in urban Burkina Faso. J Nutr. 2012;142:1748-1755. doi:10.3945/in.112.159996

11. The World Bank. Food Price Increases in South Asia. National Responses and Regional Dimensions. Washington, D.C: The World Bank; 2010.

12. Abdullah M, Wheeler EF. Seasonal variations, and the intra-household distribution of food in a Bangladeshi village. Am J Clin Nutr. 1985;41:1305-1313. doi:10.1093/ajen/41.6.1305

13. Kramer EM, Peterson KE, Rogers BL, Hughes MD. Intrahousehold allocation of energy intake among children under five years and their parents in rural Bangladesh. Euro J Clin Nutr. 1997;51:750-756. doi:1 $\underline{0.1038 / \text { sj.ejen. } 1600477}$

14. Shannon K, Mahmud Z, Asfia A, Ali M. The social and environmental factors underlying maternal malnutrition in rural Bangladesh: Implications for reproductive health and nutrition programs. Health Care Women Int. 2008;29:826-840. doi:10.1080/07399 330802269493

15. Harris-Fry H, Shrestha N, Costello A, Saville NM. Determinants of intra-household food allocation between adults in South Asia - a systematic review. Int J Equity Health. 2017;16:107. doi:10.1186/s1293 9-017-0603-1

16. Monterrosa EC, Pelto GH, Frongillo EA, Rasmussen KM. Constructing maternal knowledge frameworks. How mothers conceptualize complementary feeding. Appetite. 2012;59:377-384. d oi:10.1016/j.appet.2012.05.032

17. Rodriguez-Oliveros MG, Bisogni CA, Frongillo EA. Knowledge about food classification systems and value attributes provides insight for understanding complementary food choices in Mexican working mothers. Appetite. 2014;83:144-152. doi:10.1016/j.ap pet.2014.08.022

18. Nag M. Beliefs and practices about food during pregnancy: Implications for maternal nutrition. Econ Pol Weekly. 1994:2427-2438.

19. Piechulek H, Aldana JM, Engelsmann B, Hasan MN. Dietary management during pregnancy, lactation and common childhood illnesses in rural Bangladesh. Southeast Asian J Trop Med Pub Health. 1999;30:299-306. 
20. Shamim AA, Mashreky S, Ferdous T, Tegenfeldt K, Roy S, Rahman AK, et al. Pregnant Women Diet Quality and Its Sociodemographic Determinants in Southwestern Bangladesh. Food Nutr Bulletin. 2016;37:14-26. doi:10.1177/0379572116632137

21. The World Bank BBS, WFP. Poverty Maps of Bangladesh 2010. Key findings. 2010. https://www.wf p.org/content/poverty-maps-bangladesh-2010-key-fi ndings.

22. Pan American Health Organization UNICEF. ProPAN: Process for the Promotion of Child Feeding. Washington, D.C: Pan American Health Organization; 2013.

23. Shaheen N, Rahim ATM, Mohiduzzaman M, Banu CP, Bari ML, Tukun AB, et al. Food Composition Table for Bangladesh.; 2013. http://www.fao.org/fileadmin/t emplates/food_composition/documents/FCT_10_2_1 4 final version.pdf.

24. Bernard H, Ryan G. Analyzing Qualitative Data: Systematic Approaches. Sage: Thousand Oaks, CA, USA; 2010.

25. Braun V, Clarke V. Using thematic analysis in psychology. Qual Res Psych. 2006;3:77-101. doi:10.11 91/1478088706qp063oa

26. Stevens B, Watt K, Brimbecombe J, Clough A, Judd J, Lindsay D. The role of seasonality on the diet and household food security of pregnant women living in rural Bangladesh: A cross-sectional study. Public Health Nutr. 2017;20:121-129. doi:10.1017/S1368980 01600183X

27. Brinkman HI, Pee S, Sanogo I, Subran L, Bloem MW. High food prices and the global financial crisis have reduced access to nutritious food and worsened nutritional status and health. J Nutr. 2010;140:153s-161s. doi:10.3945/in.109.110767
28. Thorne-Lyman AL, Valpiani N, Sun K, Semba RD, Klotz CL, Kraemer K, et al. Household dietary diversity and food expenditures are closely linked in rural Bangladesh, increasing the risk of malnutrition due to the financial crisis. $J$ Nutr. 2010;140:182s-188s. doi:10.3945/jn.109.110809

29. Harris-Fry H, Azad K, Kuddus A, Shaha S, Nahar $\mathrm{B}$, Hossen M, et al. Socio-economic determinants of household food security and women's dietary diversity in rural Bangladesh: A cross-sectional study. J Health, Pop Nutr. 2015;33:2. doi:10.1186/s41043-01 5-0022-0

30. Na M, Mehra S, Christian P, Ali H, Shaikh S, Shamim AA, et al. Maternal Dietary Diversity Decreases with Household Food Insecurity in Rural Bangladesh: A Longitudinal Analysis. J Nutr. 2016;146:2109-2216. doi:10.3945/jn.116.234229

31. Choudhury N, Ahmed SM. Maternal care practices among the ultra poor households in rural Bangladesh: A qualitative exploratory study. BMC Pre Childbirth. 2011;11:15. doi:10.1186/1471-2393-11-15

32. McCrickerd K, Forde CG. Sensory influences on food intake control: Moving beyond palatability. Obesity Rev. 2016;17:18-29. doi:10.1111/obr.12340

33. Vabø M, Hansen $H$. The relationship between food preferences and food choice: A theoretical discussion. International Journal of Business and Social Science. $2014 ; 5$.

34. Olney DK, Talukder A, Iannotti LL, Ruel MT, Quinn V. Assessing impact and impact pathways of a homestead food production program on household and child nutrition in Cambodia. Food Nutr Bull. 2009;30:355-369. doi:10.1177/156482650903000407

35. Talukder A, Haselow NJ, Osei AK, Villate E, Reario $\mathrm{D}$, Kroeun $\mathrm{H}$, et al. Homestead food production model contributes to improved household food security and nutrition status of young children and women in poor populations. Field Actions Science Reports. 2010. 